Maciej MikuŁa

\title{
Żydowski samorząd ziemski w Koronie (XVII-XVIII wiek). Źródła. Wprowadzenie i opracowanie Adam Kaźmierczyk, Przemystaw Zarubin. Kraków: Ksiegarnia Akademicka, 2019, stron 679
}

\begin{abstract}
Jewish Jerritorial Self-Government in the Crown in the Seventeenth and Eigbteenth Centuries. Introduction and edition Adam Kaźmierczyk, Przemysław Zarubin. Kraków: Księgarnia Akademicka, 2019, 679 Pages

The note presents the structure of the volume, including the method of summarizing documents in the form of a short abstract and a more extensive register - in English and Polish. Attention was also paid to the research value of sources concerning the Jewish self-government in the Polish-Lithuanian Commonwealth in the seventeenth and eighteenth centuries. The volume provides valuable material for research in the field of the history of law, for example the legal grounds for judgments.
\end{abstract}

Keywords: Jewish Territorial Self-Government, Polish-Lithuanian Commonwealth, law, edition, source

Słowa kluczowe: żydowski samorząd terytorialny, Rzeczpospolita Obojga Narodów, prawo, edycja, źródło

Omawiana edycja stanowi jeden z rezultatów projektu badawczego Żydowski samorząd ziemski w Koronie XVII-XVIII wieku (Narodowy program Rozwoju Humanistyki, nr 0041/NPRH2/H11/81/2012), realizowanego pod kierownictwem profesora Adama Kaźmierczyka w Instytucie Judaistyki Uniwersytetu Jagiellońskiego. W niniejszej nocie pragnę zatrzymać się wyłącznie na kilku aspektach.

Na edycję składa się 256 dokumentów, co stanowi część bogatego materiału zebranego podczas projektu, prezentowanego także w formie elektronicznej na stronie internetowej http://www.ziemstwa.judaistyka.uj.edu.pl/katalog-ziemstw (data pobrania: 25.01.2021, 
2001 jednostek). Dwujęzyczne (polskie i angielskie) „Wprowadzenie” zawiera nie tylko przegląd stanu badań nad samorządem żydowskim w Koronie, ale stanowi sumaryczne omówienie węzłowych problemów w jego dziejach. Edycja obejmuje dokumenty podzielone roboczo na trzy grupy: wystawione przez organy Rzeczypospolitej, organy samorządu żydowskiego oraz dokumenty sądowe i inne akty istotne z perspektywy dziejów samorządu żydowskiego, które - jak zaznaczają wydawcy - nie kwalifikują się do dwu pierwszych kategorii. Każdy dokument opatrzony jest dwujęzycznym tytułem, krótko wprowadzającym w jego treść. Pozwala on na szybkie przeszukanie zawartości edycji. Następnie, oczywiście oprócz podania miejsca i daty wydania dokumentu, a także ogólnie wymaganych danych źródłoznawczych, następuje dwujęzyczny regest sumarycznie zestawiający zawartość źródła. Nierzadko regesty zajmują niemal trzecią część objętości dokumentu, przeważają jednak bardzo zwięzłe streszczenia. Zaproponowany przez wydawców podwójny opis dokumentów (tytuł i regestr, język polski i angielski), jakkolwiek jego opracowanie wymaga większej pracy, niewątpliwie ułatwia korzystanie z edycji i w wielu innych wydawnictwach może okazać się rozwiązaniem optymalnym. Warto dodać, że dziś, gdy niejednokrotnie podstawowym medium edycji nie jest już wydanie papierowe, lecz e-book lub edycja elektroniczna, argument oszczędności miejsca nie powinien być decydujący. Aparat krytyczny w dokumentach został ograniczony przede wszystkich do uwag źródłowych w przypisach tekstowych, w przypisach rzeczowych wskazane zostały m.in. identyfikacje osób wzmiankowanych w źródle wyłącznie według sprawowanej funkcji. Wydawnictwo uzupełniają indeksy rzeczowy, osobowy i geograficzny, a także słowniczek terminów staropolskich. To właśnie w indeksach znalazły się podstawowe dane identyfikujące obiekty geograficzne oraz funkcje sprawowane przez wzmiankowane $\mathrm{w}$ dokumentach postaci.

Wartość poznawcza prezentowanego zbioru, w tym dla studiów prawnohistorycznych, jest niezaprzeczalna. Dzieje funkcjonowania samorządu żydowskiego w Rzeczypospolitej Obojga Narodów stanowią niewątpliwie zagadnienie prawnohistoryczne. Niemniej omawiana edycja zawiera bardzo bogaty materiał pozwalający na podejmowanie także innych tematów prawniczych. Tylko tytułem przykładu warto wskazać, że przedmiotem zainteresowania $\mathrm{w}$ ramach studiów nad kulturą prawną jest badanie uzasadnień prawnych rozstrzygnięć. Wyraźne powołanie się na przepisy prawa nie stanowiło bezwzględnej zasady w staropolskiej praktyce prawnej. Niemniej w omawianym zbiorze można wskazać uzasadnienia prawne w kilku przynajmniej dokumentach, opatrzonych przez wydawców terminami „dekret” albo „wyrok” (nazewnictwo zazwyczaj zależy od terminologii źródłowej). W dekrecie komisarza skarbu koronnego Kazimierza Granowskiego z 1753 r. (nr 103, s. 246) przywołany został nieprecyzyjnie statut Królestwa dotyczący zapłaty pogłównego. Także w dokumentach wydawanych przez sejm żydowski znalazły się odwołania do istniejącego stanu prawnego, por. wyrok sejmu żydowskiego z 1718 r. (nr 130, s. 317) oraz dekret sejmu żydowskiego z 1730 r. Przykłady te stanowią wyraz procedowania zgodnie z obowiązującym prawem (zasada legalizmu), co stanowiło, i stanowi nadal, jedną z podwalin państwa prawa.

Zebrany w edycji materiał źródłowy będzie niewątpliwie stanowić podstawę dla licznych studiów, także z zakresu historii prawa. 